Lisbon - Malacca Port Cities Twin Conferences 2019 / 2020

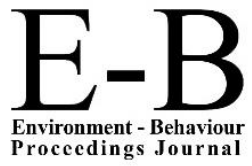

AicQoL2020Malacca

ASLI (Annual Serial Landmark International) Conferences on QoL2020

https://www.amerabra.org; https://spu.uitm.edu.my/cebs; https://www.emasemasresources.com/

8th AMER International Conference on Quality of Life

Mahkota Hotel Melaka, Malacca, Malaysia, 18-19 Mar 2020

(Due to the Covid-19 lockdown, paper virtually presented on 25 Mar 2020)

\title{
A Review on Tree Sensitive Urban Design (TSUD) Approach as Potentials Streetscape Design Guidelines
}

\author{
Nor Syafiqah Zairuddin¹, Noriah Othman², Nurhayati Abdul Malek ${ }^{3}$ \\ ${ }^{1}$ Center of Studies for Postgraduate, Faculty of Architecture, Planning \& Surveying, \\ Universiti Teknologi MARA, Shah Alam, Selangor, Malaysia. \\ 2,3 Center of Studies for Landscape Architecture, Faculty of Architecture, Planning \& Surveying, \\ Universiti Teknologi MARA, Puncak Alam, Selangor, Malaysia. \\ iqanorsyafiqah@gmail.com , noriaho@yahoo.com , nurhayati.abdmalek@gmail.com \\ Tel: +6019-311 6004
}

\begin{abstract}
Green fabrics that comprise of roadside tree planting play a vital element in an urban ecosystem. Inappropriate roadside tree planting implementation and even during its post-execution of management practices affect streetscape quality of life (QOL). Roadside tree planting condition in every country and town in Malaysia tend to have different in quality as different authority conducts management and maintenance for different area. This study is to serve as a discussion of non-numerical data on the potential of attributes and approaches that can be executed in the Malaysian context.
\end{abstract}

Keywords: Streetscape Design; Roadside Tree Planting; Tree Sensitive Urban Design Theory

eISSN: 2398-4287 @ 2020. The Authors. Published for AMER ABRA cE-Bs by e-International Publishing House, Ltd., UK. This is an open access article under the CC BYNC-ND license (http://creativecommons.org/licenses/by-nc-nd/4.0). Peer-review under responsibility of AMER (Association of Malaysian Environment-Behaviour Researchers), ABRA (Association of Behavioural Researchers on Asians) and cE-Bs (Centre for Environment-Behaviour Studies), Faculty of Architecture, Planning \& Surveying, Universiti Teknologi MARA, Malaysia. DOI: https://doi.org/10.21834/e-bpj.v5i13.2086

\subsection{Introduction}

Green fabrics deliver an extensive intangible service in promoting streetscape towards a conducive environment for the users. Theoretically, consideration of developing excelling streetscape design included the availability of space, setback, hardscape and footpath clearance, service constraint, liability, and public safety. Neglecting these key factors deteriorates the quality of air and the sequestration of carbon dioxide environmentally. Nonetheless, the unhealthiness of roadside trees always brings the risk to road users due to its lower rate of durability. This approach is to ensure the internal cycle of inputs by the roadside tree as the main component and the outputs through its benefits consistently sustain the quality of life (QOL) in Malaysia's rapid urbanization development. Local authorities in Malaysia have involved in many greening and beautification programs. The development of the city is to balance with the green fabrics where the National Landscape Department (NLD) itself has issues National Landscape Policy. The intention is to ensure Malaysia as a Beautiful Garden Nation by 2020. Over NLD, the Ministry of Housing and Local Government has worked on evolving sustainable green infrastructure in Malaysia. This effort will help to improve the quality of life of people by establishing a conducive, healthy, and pleasant quality environment (National Landscape Policy, 2011). By the year 2020, the NLP mission is to plant about twenty million trees (Noriah, 2004). As because of this, one program has launched by the Ministry of Federal Territories in planting 1,970 trees in the Federal Territories. It is in conjunction with National Landscape Day and 37,000 trees to plant in three Federal Territories by the year of 2013 (Utusan Malaysia, Jun 13, 2013). A comprehensive tree planting in bringing greenery into the grey forest through the initial

eISSN: 2398-4287 ( 2020. The Authors. Published for AMER ABRA cE-Bs by e-International Publishing House, Ltd., UK. This is an open access article under the CC BYNC-ND license (http://creativecommons.org/licenses/by-nc-nd/4.0/). Peer-review under responsibility of AMER (Association of Malaysian Environment-Behaviour Researchers), ABRA (Association of Behavioural Researchers on Asians) and cE-Bs (Centre for Environment-Behaviour Studies), Faculty of Architecture, Planning \& Surveying, Universiti Teknologi MARA, Malaysia.

DOI: https://doi.org/10.21834/e-bpj.v5i13.2086 
program of 'No Roads Without Trees' become hugely successful (Mohd A, A.K., Noriah O., 2011). However, the aim of putting the quantity over quality has created many issues on roadside tree planting. Unaware of sustainable methods in growing healthy trees, thus resulting in trees to deliver negative outputs than its supposed target to balance with the cities' concrete infrastructure. Hence, the aim of this paper is specifically at all levels of hierarchy, including government, professional sector, academia, and community. This study concern on how roadside tree planting can enhance in delivering benefits to the community, environment, and economy internally and physically. It will also include modification of climate, enhancement of air quality, habitat for urban wildlife, aesthetics, (Karuppannan S, Baharuddin Z, Sivam A, Daniels C, 2014), moderate stormwater runoff (Saraswat C, Kumar P, Mishra B, 2016), and others (Kanniah and $\mathrm{Ho}, 2017)$. In Malaysia, there are still no official guidelines or documents that advise on tree maintenance, especially on roadside trees. Appropriate management and maintenance of the urban tree planting will help to assure trees become healthy, resilient, and can survive for the long-term, thereby reducing the maintenance burden. Hence, the main objective of this paper is to accumulate and present an approach that can resolve roadside tree planting issues in streetscape design, yet improving communities' quality of life.

\subsection{Literature Review}

\subsection{Conflicts in Growing Roadside Tree Planting}

\subsubsection{Competition for Available Space}

The issue of road widening and construction of a new road has caused roadside planting to grow in limited space (Lazim \& Misni, 2016). In 2000, Thomson and Sorvig described that over the past century, specifications on conventional tree planting attend to be more concerned about crushing trees into minimum space rather than allowing plants to thrive. A buildable area for people and vehicles always demands by clients in enabling it in maximum space, which thus left a very minimum plantable space. There is still competition within the road corridor for available space in dividing it into a different range of functional and physical uses such as car parking, traffic lanes, bicycle lanes, and bus lanes. Additionally, there is also a competition within the verge space for property access, pedestrian circulation, signage, and street furniture. Other than that, both above and below ground space also undergo competition from engineering infrastructure that includes street and pedestrian lighting, traffic control devices, overhead powerlines, stormwater drainage, and belowground services, including sewerage, water supply, and electricity (Ely, 2010).

\subsubsection{Service Constraints with Underground Services}

The underground services include Common Services Trench (CST) and Sewer Line. These services always become a conflict to the plantable area as, at most of the situation, it has frequently been locating at landscape area, which indirectly created an issue in thriving green infrastructure towards a better quality of its output yet reducing the significant impact on the quality of life. There is no evidence to convince that both trees and underground services do not coexist together. Most of these underground services been located and installed at the plantable area in which trees could be severely damage whenever roots need to be cut to excavate and repair the facilities.

\subsubsection{Hardscape Conflicts}

Kerb is a narrow hardscape element that inappropriate of its implementation will cause damage to both curb and roadside tree roots. A separation at a minimum of $1300 \mathrm{~mm}$ of curb setbacks is needed between tree centreline and curb face. It will prevent damage of tree root to the curb and road pavement. In terms of footpath setbacks, a separation of minimum $1000 \mathrm{~mm}$ is required from trees to footpath in minimizing tree root damage to the footpath. This intention is to clear and unobstructed pedestrian access (PUAC,1997). However, the competition in splitting up one definite space into different functional space just lead the landscape to be given a little space that left last. Most of the roadside planting space, especially on the median planting, has been provided with a maximum 1-meter end to end width, which means the length between the curb face and centerline of the tree is only $500 \mathrm{~mm}$.

\subsubsection{Urban soils}

According to Roberts J.,N. Jackson, and M.Smith (2006), soil compaction results from human activities associated with urban development. The result can be either intentional or unintentional. Severe compaction usually causes by construction activities, especially on intentional compaction. It is to prevent uneven soil settlement below pavements and building footings. Maximum bulk densities aimed by the engineers as possible it is. It achieved when the moisture content of soils is at their optimum level. The engineers have used the Proctor test used in determining maximum bulk densities for soils and optimum water content for compaction. In the specification, soil commonly requires its maximum bulk density to be compacted to $95 \%$. However, soil compaction can also be unintentional. The compaction happened due to the loading of vehicular or pedestrian traffic that brings into soil compaction. Besides, this unintended but severe compaction also occurs during site construction. Activities such as material storage and vehicle movement lead to this conflict, too (Roberts et al., 2006). 


\subsection{Comparison of Tree Planting Guideline}

In Malaysia, both the National Landscape Department (NLD) and the Department of Urban and Rural Planning Malaysia (NURPD) have provided general guidelines in preparing yet designing street tree planting (NLD, 2011; JPBD, 2010). These include the requirement of minimum planting width and suggestion of suitable planting species. However, in comparison with Singapore Greenery Provision for Roadside (ND, 2018), Malaysia is still lacking on some technical requirements of growing roadside tree planting. These have been summarized in Table 1 below.

Table 1: Comparison of Tree Planting Guideline

\begin{tabular}{|c|l|c|c|}
\hline No. & \multicolumn{1}{|c|}{ Practices } & Malaysia Tree Planting Guideline & Singapore Tree Planting Guideline \\
\hline 1. & Planting Width & $\sqrt{ }$ & $\sqrt{ }$ \\
\hline 2. & Planting Selection & $\sqrt{ }$ & $\sqrt{ }$ \\
\hline 3. & Technical requirement: & $x$ & $\sqrt{ }$ \\
\hline \multirow{2}{*}{} & i. Aeration requirement & $\sqrt{ }$ & $\sqrt{ }$ \\
\cline { 2 - 4 } & ii. Soil Mixture Specification & $x$ & $\sqrt{ }$ \\
\cline { 2 - 4 } & iii. Clearance of Proposed Roadside Elements & $x$ & \\
\hline
\end{tabular}

(Source: Author)

\subsection{Methodology}

\subsection{Research Framework}

This research is still in progress in obtaining secondary findings. Currently, the study is at the phase of collecting non-numerical data where information is being collected by reviewing related journals, site observation, and photo evidence. There are about four main categories of the journal selected based on its appropriateness with research study, which are Social Science, Environmental Research, Science Direct, and Google Scholar. These journals have been collected for review purposed. These are by searching on related keywords such as roadside tree planting, streetscape design, quality of life, and tree management. As a result, current roadside tree planting issues and other related theory and guideline that relate to the research study have been identified. Other than that, the data will also be obtained through semi-structured interviews with landscape practitioners from a few authorities such Shah Alam Municipal Council, Klang Municipal Council, and Subang Jaya Municipal Council. The expected outcome is to gain their point of view on the level of the current practice of Malaysia roadside tree planting. All these data, later on, will be analyzed based on the information gathered in determining how the attributes from Tree Sensitive Urban Design (TSUD) Theory can be integrated into current Malaysia Roadside Tree Planting practice. The TSUD approach is to achieve sustainable roadside tree planting yet contribute to developing the best quality streetscape life. Besides, the solutions produced will enhance the gap of existing guidelines used by the authorities. Overall, this paper will serve as a discussion of non-numerical data (qualitative approach) on the potential of attributes in Tree Sensitive Urban Design (TSUD) Theory and determining the additional characteristics suggested by a practitioner in enhancing current Malaysia roadside tree planting management.

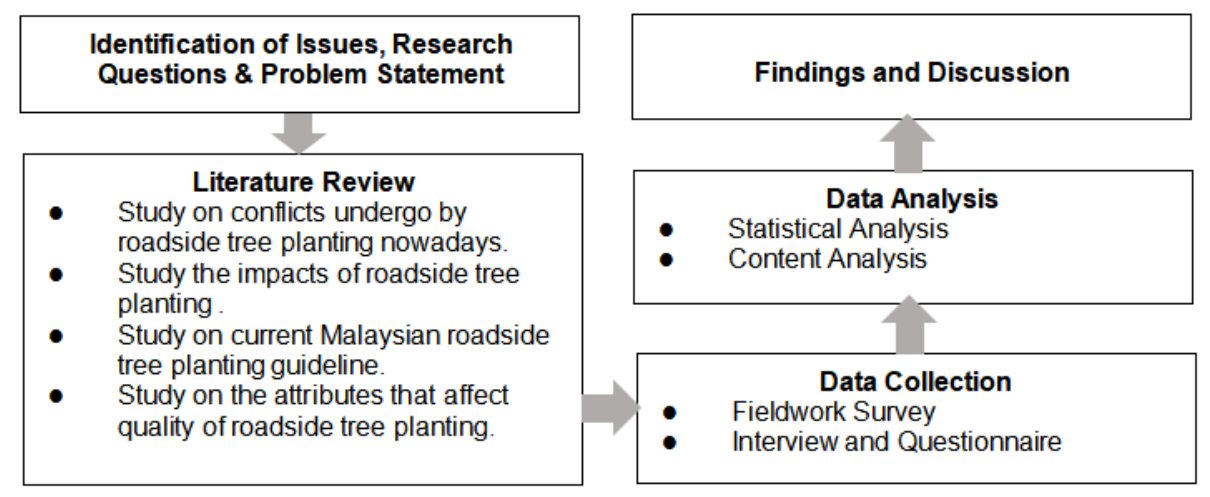

Fig. 1: Flowchart showing the conceptual framework of the research (Source: Author)

\subsection{Discussion and Findings}

\subsection{Roadside Tree Management}

The urban roadside tree involves three types of management that are establishing, maintaining and removing trees. In achieving the long term growing healthy trees, these three approaches should be applied. The main priority in managing the roadside tree is to remove hazardous trees or some of its dangerous parts. It is to ensure the safety of people while using the road. Another most crucial stage 
reported in tree pruning activity in tree maintenance which is stated as the most harmful and costly activity (Murad, 2000). In 1990, Nowak, in his study, indicated that about $30 \%$ of the budget for tree care in a city was allocated for trimming activities and another $28 \%$ was used for tree removal and disposal. These happened when the tree is just too close in proximity to the urban communities due to its condition that achieved mature and over-matured size. This condition has led to an increasing number of complaints from the public. These issues have led more than ten thousand Ringgit Malaysia the need to spend by local authorities to pay the compensation (Yaman A, Jamil M, Yaakob R, 2011). At the time, the organization within tree management itself plays a crucial part in ensuring optimum quality of roadside tree planting. The inadequacy of training facilities and opportunities between employees has resulted in various problems causing hazardous trees cannot be managed effectively. However, inadequate or even minimum space that left for planting bring some practitioner to plant the tree without putting extra concern on how to sustain the tree with on-site limiting factors. Figure (a) and (b) below shows site observation images on some condition of roadside tree planting in Bandar Kinrara, Puchong.
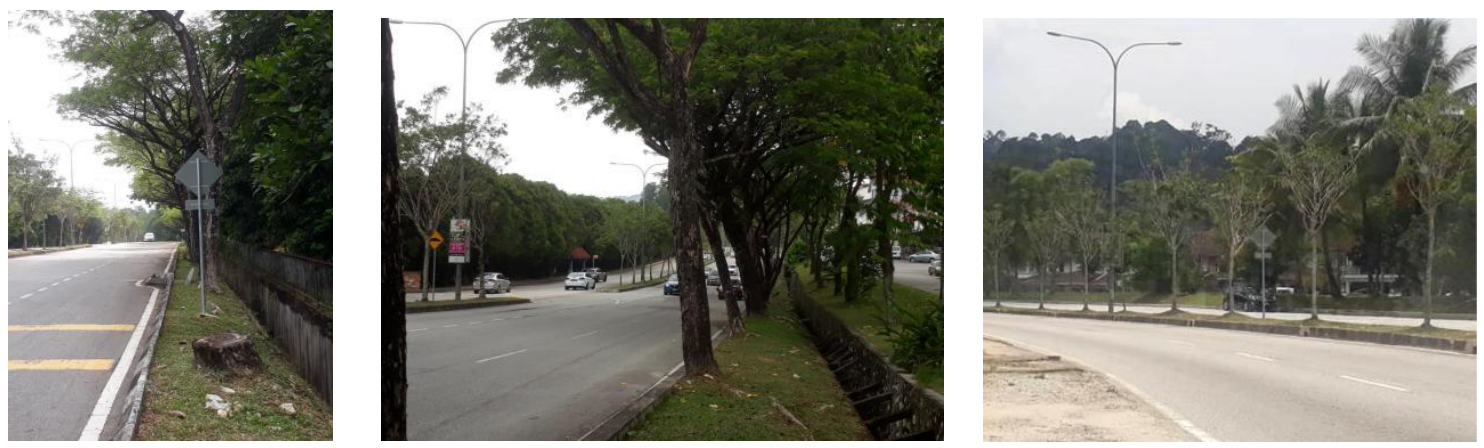

Fig. 2: (a), (b), (c) : Conditions of roadside tree planting due to the hardscape conflicts

(Source: Author)

\subsection{Developing Healthy Roadside Tree Planting}

In the previous study, the author has highlighted the overall theory of Tree Sensitive Urban Design by Ely (2010). There are two principles in developing best management practices which are structural principles and non-structural principles. However, this study will focus indepth on the structural best management practice that include a few attributes on tree planting practices. The author highlighted five practices and further description are as below.

\subsubsection{Tree selection based practices}

In reducing conflicts on infrastructure, appropriate tree species selection has always been suggested by selecting a proper size of the tree in following planting space. Other than that, this planting selection also can be made by taking concern in avoiding species that have characteristics to invent a conflict with the infrastructure (Castello \& Jones 2003). Successful roadside landscape management can be achieved whether choosing native or introduced tree species as long as its growing requirements and elements fit both living and non-living structures. However, the most vital part need to concern is to avoid species that have a higher potential in bringing damage to the other nearest element. Those elements includes a plant that has root buttress, massive trunk flare, and those with roots that tend to grow at the surface of the soil. Due to the growth of conflicts on roadside tree planting, many arborists admit that tree selection is essential to reduce disputes between pavement and tree (Harris R, Clark J and Matheny, N.P, 2004). According to Ramly (2018), the selection of trees has been observed, and the analysis shows that the plant selection in some urban areas in Malaysia is not in accordance with planting location thus cause the stated tree problems.

\subsubsection{Root zone-based practices}

Root zone-based practices included the management of soil and the use of root barriers. The amount of repairing broken pavement and other hardscape elements caused by tree roots cost about millions of dollars annually. This conflict has happened when the urban space allows just too little plantable space for tree root systems to develop and survive naturally. As because of that, damage to nearby nonliving infrastructure is expected. Installation of surround-type root barriers is often specified as a means of preventing damage from future root growth when a new street or parking lot trees are planted. While surrounding a newly-planted tree's root ball, the root barrier may become one of the ideal solutions in these root-space limited sites. Other than that, the use of structural soils also becomes another choice for good quality rootzone practice. This method will allow roots to explore at deeper levels due to its improved below zone conditions. Another approach is 'root baiting'. This concept explained that roots will avoid areas that have inadequate resources for growth, and will find resources elsewhere (Coder 1998 and Costello \& Jones 2003).

\subsubsection{Tree Pit Design Practices}

A particular design solution is required to ensure a constraint tree pits in the urban area that surrounded by hard paved surfaces can deliver its benefit at the optimum level. A few practitioners and researchers have identified current 'best practices' based on the biological requirements of trees (Craul \& Craul 2006; Balsamo 2008). These requirements are as listed below: 
a. Excavate the hole approximately three times larger than the root ball.

b. Avoid vertical pit walls, but rather flare the walls out in a 'wok' shape to increase the size of the mulched opening.

c. The root ball should be placed on a firm surface to avoid future settling and risk of collar rot.

d. Roughen the tree pit walls if they are smoothed during excavation, to facilitate root penetration.

e. Provide adequate drainage by breaking through any compacted layers, or installing under drainage. As a guide, the tree pit can be filled with water, and the rate of drainage observed.

f. Backfill with the original unamended soil removed from the tree pit.

g. Slope backfills upwards from the trunk to create a watering bowl.

h. Cover with mulch to the recommended thickness, leaving a space between the trunk and mulch to avoid collar rot.

\subsubsection{Extended Rooting Spaces}

Method of extending the rooting spaces can be categorized into three types which are shared rooting volume, tree islands, and linear tree pits. The value of creating 'shared rooting volumes' has been emphasized by a few authors recently. The intention is to create a much larger space for planting by putting a group of trees together in one more extensive area. Moreover, tree pits also can be interconnected with a form called 'soil trench'. Previous studies by Urban in 1996 suggests that two trees will grow larger when planted in a certain soil volume compared to a single tree with half that volume. Large common tree planting pits can be created where space exists in broad open medians or verges (Costello et al., 2000). Apart from that, Urban (1996) also recommends creating a 'tree islands'. Tree island is formed by classifying areas that can plant several trees in a large pit with its soil volume is to be shared. The benefit of applying large areas and volumes of planting medium is to allow much more effective management of soil nutrient and compaction, oxygen and water status. More than that, creating a 'linear tree pits' is another solution. It is also known as 'soil trenches', 'continuous trenches' and 'root trenches'. The primary purpose of connecting tree pits by an open verge, or by connecting tree pits beneath pavements is to use structural soils as a support to the pavement.

\subsubsection{Proper Pruning Drive to Healthy Roadside Tree Planting}

Trees are typically pruned to maintain their health, safety and aesthetic values. However, pruning can also be one of the worst things that can be done to a tree. Improper pruning leads typically to wounds which recover very slowly, depending on the size of the cut and the health of the trees (Bobrowski, Zamproni, Maria, \& Biondi, 2017). Pruning with the inappropriate method will cause an opening for insects and allow diseases to infect a tree. As a result, it will unfavourably affect the strength and health of the tree. Selecting appropriate tree species for specific critical locations can shorten the necessity for pruning yet indirectly reducing the cost for pruning. There are a few types of pruning that each type is to be implemented for different demand and situation. Topping is the indiscriminate cutting back of tree branches to stub the branches that are not large enough to assume the terminal role. This type of pruning method is to prevent interference with overhead utility lines. Unfortunately, topping can cause injury in trees in various ways. Trees that are topped usually produce vigorous water sprouts which often grow back to their original height to become denser at a faster rate. Water sprouts from the topped portion tend to have weak attachments with the main trunk, making the branches weak. It is essential to make proper cuts when pruning trees. This is because, flush cuts produce large wounds which heal slowly (Skovsgaard, Ols \& Mc Carthy, 2018). Hence, it exposes the wound to decay organisms. Properly pruned branches generally have a circular closure around the wound. Branches that have been cut too close to the trunk on the contrary will result in the closure of callus to either be oval or distorted. Wounds that are not closed by callus will invite decay organisms and bacteria to invade the tree, which will then further weaken the tree structure.

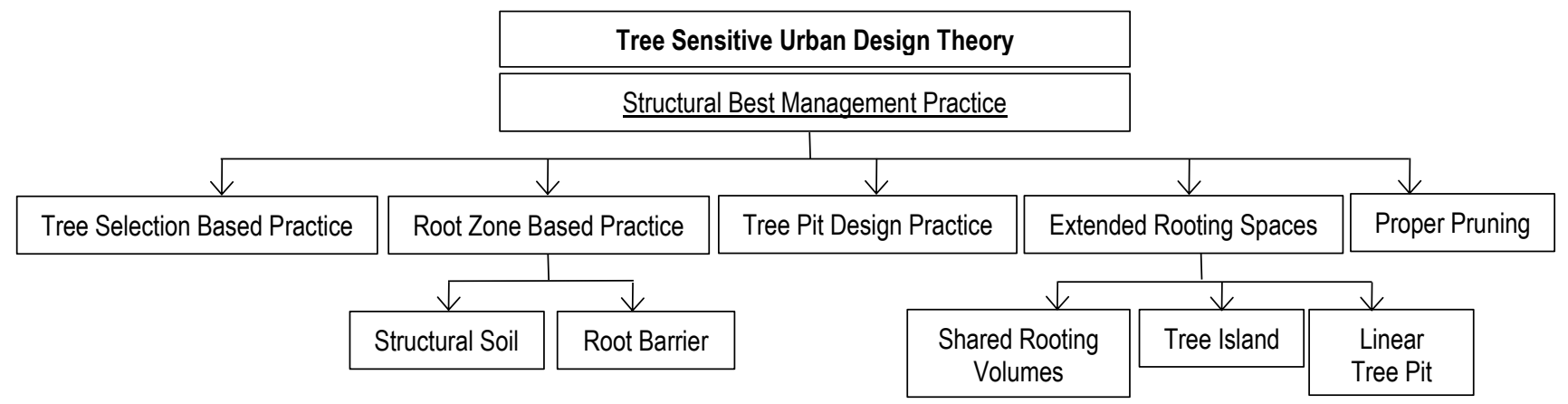

Fig. 2: Attributes in Structural Principles of Tree Sensitive Urban Design Theory

(Source: Author)

\subsection{Conclusion \& Recommendations}

This study was conducted to discuss the potential attributes to be adapt and adopt in Malaysia Roadside Tree Planting Guideline. Throughout the literature review study stage, the author has concerned about crucial conflicts that happen by roadside tree planting within the congested structural environment. The conflicts studied by the author, thus bring the author to classify some potential attributes 
in bringing current Malaysian roadside tree planting towards better quality guidelines. These included the solutions for below the ground zone, ground plane, and above the ground zone. Below ground zone plays the most crucial part in bringing the quality to the tree as most of the conflicts contributed from this zone. As because of that, the potential attributes that related to these issues are by focusing on its root zone based practices, tree pit design practices, and the extended rooting spaces. Ground and above ground zone is the most visible part where its condition can be observed directly. The best management practice for these two zones is by selecting appropriate tree species and applying the good and right pruning method. Both tree selection and pruning method affect the quality of trees not only in the visual aspect but in terms of how it can sustain long-lasting in bringing good quality benefit. Finally, this study is still in progress with data collection. However, it is hoping that the understanding of crucial methods in sustaining roadside tree planting is concerned by others, especially the authorities, as they play a significant role in ensuring roadside tree planting can supply its benefit at the optimum level.

\section{Acknowledgement}

This study was made possible by the continuous support from IRMI, Universiti Teknologi MARA for providing the funding support through the Research Grant Dana Universiti Cawangan Selangor DUCS 2018 600-UiTMSEL (PI. 5/4) (057/2018).

\section{References}

Balsamo, D. (nd). Planting Trees in Urban Situations for South Eastern Australia. Melbourne, Victoria, Treelogic.

Bobrowski, R., Zamproni, K., Maria, T. R. B. D. C., \& Biondi, D. (2017). Variability and Balance of Crown Projection of Trees Planted on Sidewalks of Three Brazilian Cities. Cerne, 23(3), 321-327.

Coder, K.D. (1998). Root Growth Control: Managing perceptions and realities. The Landscape Belo Ground II, San Francisco,California, International Society of Arboriculture.

Costello, L.R. and K.S. Jones (2003). Reducing Infrastructure Damage to Trees: A Compendium of strategies. Cohassat, CA, Western Chapter of the International Society of Arboriculture.

Costello,L.R., E.G. McPherson, D.W. Burger and L.L. Dodge (2000). Strategies to Reduce Infrastructure Damage by Tree Roots: Proceedings of a Symposium for Researchers and Practitioners, Cohassat, CA, Western Chapter, International Society of Arboriculture.

Craul, T.A. and P.J.Craul (2006). Soil Design Protocols for Landscape Architects and Contractors. Hoboken, New Jersey, John Wiley \& Sons Inc.

Ely, M. E. (2010). Integrating Trees into the Design of the City: Expert Opinions on Developing More Sustainable Practices for Planting Street Trees in Australian Cities. Climate Change 2013 - The Physical Science Basis, (September), 1-30. https://doi.org/10.1017/CBO9781107415324.004

Harris, R.W., Clark, J.R. and Matheny, N.P. (2004). Arboriculture: Integrated Management of Trees Shrubs and Vines. Prentice Hall, Harlow.

JPBD, S. T. and C. D. (2010)."Manual Garis Panduan dan Piawaian Perancangan Negeri Selangor." Retrieved from http://www.jpbdselangor.gov.my

Kanniah K.D., Ho C.S. (2017) Urban forest cover change and sustainability of Malaysian cities, Chemical Engineering Transactions, 56, 673-678.

Karuppannan S., Baharuddin Z.M., Sivam A., Daniels C.B. (2014). Urban Green Space and Urban Biodiversity: Kuala Lumpur, Malaysia, Journal of Sustainable Development, 7, 1-16.

Lazim, R. M., \& Misni, A. (2016). Public Perceptions towards Tree Risk Management in Subang Jaya Municipality, Malaysia. Procedia - Social and Behavioral Sciences, 222(June), 881-889. https://doi.org/10.1016/j.sbspro.2016.05.210

Murad (2000). Hazard Evaluation of Mature Urban Trees in Kuala Lumpur.Unpublished Master thesis. Universiti Putra Malaysia.

Mohd Akmal, A. K., \& Noriah, O. (2011). Towards a Better Tomorrow: Street Trees and Their Values in Urban Areas. Procedia - Social and Behavioral Sciences, 35,267 -274 .

National Landscape Policy (2011).Garis Panduan Landskap Negara

National Parks (2018). Guidelines on Greenery Provision and Tree Conservation for Developments Version 2

Noriah Othman (2004). A Cross Cultural Comparison on Preferences Towards Selected Urban Landscape Planting Compositions. Unpublished doctoral dissertation,Universiti Teknologi MARA

Nowak, D.J., J.R. McBride, and R.A. Beatty. (1990). Newly planted street tree growth and mortality. J. Arboric. 16(5):124-129.

PUAC (1997). Services in Streets: A Code for the Placement of Infrastructure Services in New and Existing Streets. Adelaide, SA, Public Utilities Advisory Committee. 
Ramly, H., Noriah, O., and Faridah, I. (2018). Developing Malaysian Roadside Tree Species Selection Model in Urban Areas. Unpublished doctoral dissertation,University Teknologi MARA

Roberts, J.,N. Jackson, and M.Smith (2006). Tree Roots in the Built Environment. Norwich. The Stationary Office.

Saraswat C., Kumar P., Mishra B.K. (2016). Assessment of Storm water Runoff Management Practices and Governance Under Climate Change and Urbanization: An analysis of Bangkok, Hanoi and Tokyo, Environmental Science \& Policy, 64, 101-117.

Skovsgaard, J. P., Ols, C., \& Mc Carthy, R. (2018). High-pruning of silver birch (Betula pendula Roth): Work Efficiency as a Function of Pruning Method, Pole Saw Type, Slash Removal, Operator, Pruning Height and Branch Characteristics. International Journal of Forest Engineering, 1-11.

Urban, J. (1996). "Room to Grow". Landscape Architecture 86(3):74-79

Yaman, A. R., Jamil, M. Z., \& Yaakob, R. (2011). Manual Pengurusan Risiko Pokok. 